\title{
Solidarity and Community: Thinking Today with Jan Patočka
}

\begin{abstract}
It is difficult to speak about Patočka's political philosophy because he didn't analyze at the conceptual level issues such as democratic functioning, social justice or state theory. However, Patočka's originality consists in analyzing from a phenomenological point of view such notions as community, war, history, polemos and solidarity. According to him, political life is not only characterized by antagonism, but also by solidarity. The traditional concept of social solidarity refers to the mutual responsibility that is established between members of a social group on a common ground. Being in solidarity with others requires becoming part of a whole in which the differences between the parties become invisible. In other words, the concept of social solidarity seems to lead us towards an understanding of community that rests upon a common and solid foundation, or a final purpose. Patočka criticizes this kind of political and social foundationalizm. Political solidarity is a unity of individuals each responding to a particular situation of injustice, oppression, social vulnerability. Those who join in a solidarity of the shaken do not obtain a common ground which shapes society. The solidarity of the shaken is the solidarity of those who have lost their trust in all forms of ideological, economic and spritual mobilization of society because of a decisive event. Thinking about political solidarity allows us to think about the emancipatory possibility of social action and the obstacles to the realization of these possibilities.
\end{abstract}

Keywords: Community, Solidarity, Polemos, Vulnerability, Civil Disobedience.

\section{Dayanışma ve Topluluk: Günümüzü Jan Patočka ile Düşünmek}

Öz: Patočka'nın siyaset felsefesinden bahsetmek epey güçtür çünkü o kavramsal düzeyde, demokratik işleyiş, sosyal adalet ve devlet teorisi gibi konulara eğilmemiştir. Ne var ki onun kendine özgü tutumu topluluk, savaş, tarih, polemos ve dayanışma gibi kavramları fenomenolojik bir bakışla ele almaya ilişkindir. Patočka'ya göre siyasal yaşam sadece antagonizma ile değil dayanışma ile de anlaşılabilir. Dayanışma kavramına geneleksel bir bakış açısından baktığımızda sağlam bir zeminde belli bir kimlik içerisinde paylaşılan bir biraradalık akla gelir. Bu bağlamda toplumsal dayanışma kavramı, belli bir toplumsal grubun üyeleri arasında sağlam bir zeminde kurulan karşsllklı sorumluluk anlamına gelir. Başkalarıyla dayanışma içinde olmak, sağlam ve sıkı bir birlik meydana getiren bir bütünün ve kimliğin parçası olmak anlamına gelir. Öyle ki bu bütün 
içerisindeki katılımcıların aralarındaki farklılıklar bütünün kendisi göz önüne alındı̆̆ında görünmez olur. Dolayısıyla geleneksel dayanışma fikri bizi ortak ve sağlam bir temel üzerine kurulan bir topluluk tanımına götürür. Patočka bu tarz bir toplumsal ve siyasal temelciliği eleştirir. Siyasal dayanışma her seferinde belli bir adaletsizlik, baskı ve toplumsal yaralanabilirlik durumuna toplulukların verdiği tepki ile ortaya çıkar. Sarsılmışların dayanışması belirleyici bir olay yüzünden toplumun tüm ideolojik, ekonomik ve ruhsal mobilizasyon biçimlerine güvenlerini kaybedenlerden oluşur. Çek filozofun betimlediği siyasal dayanışma belli bir kimliğin bir araya getirdiği bireylerin üzerinde eyleyecekleri bir zemin değil, baskıya ve haksızlı̆̆a uğrayan bireylerin birbirlerinin sorumluluğunu alması ve birbirleri için mücadele etmesidir. Siyasal dayanışmayı düşünmek, toplumsal pratiğin özgürleştirici olanağını ve bu olanakların gerçekleşmesinin önündeki engelleri düşünmemizi sağlar.

Anahtar Kelimeler: Topluluk, Dayanışma, Polemos, Yaralanabilirlik, Sivil İtaatsizlik.

Today when we speak of a political dissident, we speak of a person who no longer recognizes the legitimacy of the political authority which s/he has to submit. The dissident is not an opponent from elsewhere, an external disturber. What makes her/him efficient is that the dissident comes from the system s/he criticizes. The dissident is the typical fruit, sometimes even the model product. This makes her/his protest more effective and audible for all (Eltchaninoff 2016: 18). The dissident is not a violent rebel, nor a clandestine fighter. What $s /$ he considers to be his strength rests on non-violence, personal principle and transparency. The Dissident's approach is ethical. Today the dissidents reappear in countries where democracy has not won or in countries of false democracy and in areas of conflict. Such refusals of the established order and of given meaning entails risks and exposure. The political life of a dissident refers to combat and struggle but these notions are not enough to express the feeling of suffering and indignation (thumos) involved in dissent. The resistance of dissidents presupposes a certain type of vulnerability created by existential insecurity under authoritarian regimes. It has meaning only as a non-submission to power, as an activity. The recognition of the vulnerability is not only a subjective description but is potentially a mobilizing force for resistance. In this respect, what will be the political consequences if we think of vulnerability as the condition of possibility of 
political resistance? If vulnerability is part of the meaning and action of resistance how can we then reinterpret the political dimension of dissidence? Following Patočka's analysis of theory of the solidarity of the shaken, which describes a resistance to a permanent state of war in the form of dehumanizing total mobilization, I aim to show the role of the recognition of vulnerability in the practices of political resistance and civil disobedience.

\section{Total Mobilization and Technical Age}

In the sixth of his Heretical Essays, "Wars of the 20th Century and the 20th Century as War", Patočka tries to understand the authentic aspect of the Front-line experience. This essay begins with an examination of the character of the First World War, a war that Patočka calls "the decisive event" of the century, determining "its entire character." (Patočka 1996: 124). As Edward F. Findlay writes, "it is important to note that this essay, more so than the earlier parts of the Heretical Essays, is a text whose clear context is the struggle of Czechoslovak dissidents against the communist regime. It draws on specific aspects of that philosophy of histroy and applies them to twentieth-century politics" (Findlay 2002: 136).

According to Patočka, the front-line experience reveals the pre-given meaning of the modern world and its total dehumanizing mobilization. In the form of total mobilization, war expresses the metaphysical essence of technological modernity as a will to power. However, the total mobilization of the First World War did not end in 1918 but instead continued in other forms. What comes after

the war is neither peace nor war, it is a war against the war. The war continues in peace and continues to form the social existence of man.

The example of the Cold War is characteristic of this more or less violent confrontation between two entities, the United States and the Soviet Union, each having presented itself as the repository of the values of humanity and its defense 
by force. Patočka analyzes this situation from an opposition between what he calls "the forces of the day", life and peace, and, on the other hand, night, death and war. According to him, it is paradoxically the forces of the day, the life and the peace which are behind the destructive conflicts of the 20th century despite the millions of victims who were sacrificed (and perhaps even thanks to them). What does this paradox contain? How to understand it?

The "forces of the day" designate all the mechanism of super-civilisation or the technical age (the age in which humanity takes on the endless accumulation of power as the ultimate political goal) and intend to manipulate the being to master it. It is then that two meanings of sacrifice are opposed, and with them two relations to death. The first refers to a thought of "life and death" which has a power of alienation. It is an inauthentic sacrifice and it is for something positive. The power of freedom and disruption of authentic sacrifice opposes to the power of alienation and instrumentalization of sacrifice (Crépon 2007: 404). There is a negative force in sacrifice, a form of protest and resistance against a state of fact, a mode of being. It has a destablising dimension of crystallized social structures. This form of sacrifice should not be understood by its effects and cannot be justified by its results. It lies in the knowledge of human vulnerability, of the vulnerability of our freedom, and in the need to protect it. The understanding of human vulnerability makes possible both sacrifice and the communication of the meaning of this sacrifice to others. But, according to Patočka, (Patočka 1996: 126) yet in the depth of that experience (front-line experience) there is something deeply and mysteriously positive. The person on the front line is gradually overcome by an overwhelming sense of meaningfulness which would be hard to put into words. What is this overwhelming sense of meaningfulness?

First, the front is the experience of meaninglessness and unbearable horror and the absurdity of the world. For Patočka this meaninglessness is the origin of meaning - it is only by and through the experience of the complete absence of all 
meaning that the very question concerning meaning becomes meaningful 1 . The constant shaking of the naive sense of meaningfulness is itself a new mode of meaning. Secondly, this vision of the end is at the same time a progress behind the limits of existence. The man who experiences his limits, his being-for-death, is necessarily shaken by the emergence in him of a concern other than that artificial peace for which the forces of the day make him fight. He reaches a summit which is subordinate to nothing real. This summit makes him break with the values of the day which enjoin him to preserve his naive life by the divestment of self in things ${ }^{2}$. In life for death opens the ethical horizon of absolute freedom which obliges man to become aware of his status as subject, responsible for his choices and actions in a world whose meaning remains ambiguous, problematic. Only those who consent to the most radical sacrifice are capable of attaining to this clairvoyant freedom, the freedom of the intrepid who understands the limits of real human laws. As Patočka writes, "It is to comprehend that here is where true drama is being acted out; freedom does not begin only 'afterwards' after the struggle is concluded, but rather has its place precisely within it" (Patočka 1996: 134). However, the problem of the experience of the front is that it has remained an exclusively individual experience. Everyone is projected alone towards a freedom of which he is aware but which he can not transform into a collective event. The front had no purely political consequences. The only way to overcome this state of affairs would then be the "solidarity of the shaken". The enemy participates in the same situation as

\footnotetext{
${ }^{1}$ As Patočka writes: "Passing through the experience of the loss of meaning means that the meaning to which we might perhaps return will no longer be for us simply a fact given directly in its integrity; rather, it will be a meaning we have thought through, seeking reasons and accepting responsibility for it. As a result, meaning will never be simply given or won once and for all. It means that there emerges a new relation, a new mode of relating to what is meaningful; that meaning can arise only in an activity which stems from a searching lack of meaning, as the vanishing point of being problematic, as an indirect epiphany. If we are not mistaken, then this discovering of meaning in the seeking which flows from its absence, as a new project of life, is the meaning of Socrates's existence. The constant shaking of the naive sense of meaningfulness is itself a new mode of meaning, a discovery of its continuity with the mysteriousness of being and what-is as a whole" (Patočka 1996: 60).

${ }^{2}$ It is a refusal of the values and pre-given meanings of the natural world and it strips the subject of its worldly preoccupations.
} 
us, he discovers with us absolute freedom. As Patocka writes: "the enemy is no longer the absolute adversary in the way of the will to peace; he is not here only to be eliminated. The adversary is a fellow participant in the same situation, fellow discoverer of absolute freedom with whom agreement is possible in difference" (Patočka 1996: 131). Against the forces of the day which does nothing but deepen the ideological, economic and spritual mobilization of society, Patočka puts forward the absolute freedom of the experience of the front and solidarity of the shaken as an authentic answer. "The solidarity of the shaken -shaken in their faith in the day, in 'life' and 'peace'- [...] can say 'no' to the measures of mobilization which make the state of war permanent. It will not offer positive programs but will speak, like Socrates' daimonion, in warnings and prohibitions" (Patočka 1996: 135). This experience of withdrawal echoes a similar reversal in Patočka, in the form of the redefinition of philosophy as the care of the soul in its political and ethical dimensions. In fact, it is the Socratic experience that allows this deepening of human freedom. Man is responsible for the sense which engages him in the care of the soul not only of his own soul, but of the soul in general, responsible for justice in the community. In the shaken community, war is no longer simply experienced from the outside as an experience of suffering and of negation. It is experienced internally as an affirmation. Pain is not forgotten but it is now interpreted as that which intensifies the relation to oneself. The seized and sustained pain in the amplitude teaches us to discover the world and shows us that we are free as to the interpretation of its meaning.

However, how can we understand an alternative path to antagonism? Patočka proposes an archaeological reflection of the community of shaken thanks to its re-reading of the Heraclitean vision of being as polemos. This would indicate a partly divergent but perhaps complementary path of the phenomenological approach and maintain a dynamic of argumentation on the theory of solidarity of the shaken. The polemos does not only mean discord but also the unity produced by this discord. Like the front in the war, the space of the polis reveals the 
inequality of the social relations and puts in scene a certain field of the conflict. As Patočka shows, such a polemic unity is the common point between soul and polis. The polis can be described as the soul which is the very place of the conflict between the passions and the reason, between the desires and the logos. In this sense, the real meaning of conflict, which can appear in exceptional circumstances on the front, is the reality of politics. We must therefore broaden our interpretation of the solidarity of the shaken and the experience of the front of the war towards the political and ethical field of polis. In the figure of the soldier succeeds that of the citizen.

\section{Political Life and Solidarity}

Let us note that, in order to describe the political life of the shaken, the idea of solidarity must be analyzed again in its political context. The concept of solidarity refers to the mutual responsibility that is established between members of a social group on a solid and common ground. Being in solidarity with others requires becoming part of a whole in which the differences between the parties become invisible. Social solidarity thus traditionally has to do with solidity, it consists in forming a union with others on the firm and stable ground of a shared identity. However, it is precisely this solidus or common ground that for Patočka is shaken (Stranberg 2015: 101). Those who join in a "solidarity of the shaken" do not obtain a common ground; it is a solidarity brought about by existential upheaval and disorientation, not by sharing something but, in a sense, by sharing nothing. In fact the only unifying aspect of this solidarity is found within the abyss of meaning itself, in the nothingness of a commun loss: in the common loss of a common ground. It is therefore solidarity beyond solidity. It is an experience of confrontation with finitude and lack of meaning, of strangeness and Angst in Heidegger's terms. Nevertheless, according to Heidegger, Angst is not a collective experience. Like Husserl's epoche, which allows us to pass from the natural 
attitude to the philosophical attitude, Heideggerian angst returns Dasein in the daily publicity of the one towards the possibility of its own.

However, according to Patočka, when it comes to the solidarity of the shaken, the experience of anxiety is a collective and historical experience. Even if the Czech philosopher retains the formal structure of the experience of anxiety, it is not limited exclusively to the phenomenon of individual anxiety, because the shock of the given meaning has an influence on the whole community. Solidarity is thus in the perspective of an authentic being-with, realized in political life and is unconditional. It does not rest on anything but itself, except on the care of our soul which is concerned with our humanity as such. According to him, the emergence of the political life of the Greek polis, understood as an entrance into the historicity and into the problematicity of meaning, results from such a shaking of meaning of the mythical order. The polis is the name given to space devoted to the collective questioning of meaning. The "shaking of meaning" here means the questioning of meaning and the loss of the accepted, given, and established meaning. It leads the political community to constantly build its own meaning. As Patočka writes: "There is not only struggle but also solidarity, there is not only society, but also community, and community has other bonds besides a common enemy" (Patočka 1996: 149).

Solidarity is therefore an authentic experience of being-with which is realized in political life. It is a unity of individuals who have made a commitment to struggle for liberation. In this regard, the community of the shaken is more than an aggreage of its parts. On that basis the solidarity is not only a moral concept and the political solidarity has a different structure than a social solidarity. "The logic of political solidarity, reverses the ordering between social bonds and moral obligations found in social solidarity" (Scholz 2012: 36).

Political life is perpetually in search of its own foundation which is not a secure life but freedom. It is not only characterized by antagonism but also by 
solidarity (Patočka 1996: 207). It opens man to his fundamental possibility as life in amplitude. In a text entitled "Balance and Amplitude in Life" which dates from 1939, Patočka speaks about life in amplitude:

\footnotetext{
Life in amplitude means both self-testing (épreuve) and protesting. In amplitude, man exposes himself to extreme possibilities that, in ordinary life, remain abstract and remote, and protests against those which, from the viewpoint of the everyday, seem self-evident (Patočka 1990: 36).
}

Any human activity understood as amplitude is a trial, an ordeal, a protest; it is the rejection of the daily sphere where life is most often captive, where we keep our eyes closed to the truths and the perils of our existence. It is a search for truth and a protest against daily life as it takes place, against our fascination with the limits which are imposed on us and which we impose on ourselves, and against our fear of what we find trying. According to Patočka, the one who assumes this possibility is free in the deep sense of the term. By accepting the peril, freedom gains complete security, assures the man of a life lived from its own foundation, from what it is in its principle. Through the struggle which freedom causes him to engage with himself, man becomes master of his own being, of what is deepest in him, of the most extreme depth that he is capable of reach.

\section{Vulnerability and Disobedience}

The issue of the debate on the solidarity of the shaken is not only social, it is also a political issue. Political solidarity is a unity of individuals each responding to a particular situation of injustice, oppression, social vulnerability. The solidarity of the shaken is a community of vulnerability to the other absolutely necessary and primordial, and it is only as such that it can be a free and historical community. Vulnerability must be seen as a fundamental human condition that requires both an ethical response and political action. In my reading, such a path of thought must be constructed to the experience of events, in the related research of their elucidation and the determination of the conditions for political action. 
The questions we can ask now are: may the solidarity of the shaken be used as a theoretical guide to deepen contemporary philosophical research on the movements of civil disobedience? If vulnerability is part of the meaning and action of resistance, how can we then reinterpret the political dimension of dissent? To answer these questions, we need a phenomenological approach to social movements and civil disobedience as the political practice of dissidents. This will allow us to conceptualize the collective action of new dissidents and solidarity on the basis of the relationship between vulnerability and resistance. In this regard, Patočka's political sense of resistance to the total dehumanizing mobilization of war can help us to re-read the commitment to insubordination as well as the resistance of social movements. This closeness invites us to reflect also on the relationship between the dissident attitude whose foundation is presented as ethics and the solidarity of the shaken as a model of political commitment. The two axes of reading are linked by the question of vulnerability and its eminent political significance.

Social movements that take the form of gatherings and occupations of places, protest movements against the existing powers, civil insurrections, are all mobilizations that call for dissent from the established order and power in place. Contemporary uprisings have all shown, despite what distinguishes them culturally, ideologically and historically, how a community of vulnerable subjects becomes political by taking possession of a space and time of their own, creating an another common world. Each uprising is an unexpected initiation into pain, suffering and decomposition as well as into a solidarity of the shaken. These uprisings simultaneously demand democracy and contribute to renew the social and political sense of the public space by a voluntary association.

The symbolic dimension and the practical functioning (blocking or occupation) of disobedience is the solution that is necessary when there is a collective vulnerability and a need for political solidarity. Political solidarity, unlike 
social solidarity, arises in response to a situation of injustice or oppression. It tries to offer means of expression to those who do not, because today the question of the political life of a dissident is a matter of expression. In its phenomenological aspect, the political question becomes that of expression and of appearance in political space. Political space is not only a space of representation, but also a type of phenomenal space. Political struggles aims at transforming the functioning of politics by revealing invisible vulnerabilities and the capacities of the voiceless subjects. This is the emergence of a democratic practice of collective selfdetermination to combat the erosion of political institutions and the narrowing of the political field.

As the definition of "Life in amplitude" of Patocka, civil disobedience has the meaning of both self-testing (épreuve) and protest, and it is on the basis of this structure that one can understand its meaning. Thus, it is not only a crowd that advances in the street or a group that intervenes to break the order of things. It is a difficulty that causes suffering and a claim to justice as a form of resistance. It helps to highlight the ethical principles that motivate those who disobey the law, not for themselves, but to defend a cause superior to their own interests (not only for the good of justice but also for the good and value of democracy). Like dissidence, civil disobedience is a tool of democratic struggle that makes it possible to reconcile the ethical demand with the radicality of the action. It consists in opening up the political landscape on which collective action must be expressed in order to try to change unjust laws and to oppose a governmental policy that violates fundamental human rights. It is therefore an ethical as well as a political choice

In his book entitled Philosophy and Resistance in the Crisis, Costas Douzinas thematizes the link between trial and protest:

Disobedience negates, resistance creates. The importance of disobedience lies precisely in the process of production of new subjectivities. It raises people from takers of orders and commands into self-legislating citizens (Douzinas 2013: 98). 
The importance of civil disobedience lies precisely in starting the process of production of new collective subjects. As in the solidarity of the shaken, it features unexpected political encounters that cannot be defined by a juxtaposition of ideological, social or ethnic identities. Participants in civil disobedience gain their "dissident" identities through their reciprocal actions in solidarity. It means that their community is not a "property" belonging to subjects that join them together. What is common is not that which unites ideological, social or ethnic property of every one of its members. They have not a shared consciousness or a common mode of political organisation but only a kind of collective vision and desire for the future. The subjects of community are united by an obligation. This is what expropriates them of their pre-established subjectivity. In that community subjects do not find a principle of identification or a harmonious field. According to Saul Newman, this situation creates a new paradigm, a reformulation of the practice of politics, which he characterise as politics of anti-politics:

\begin{abstract}
However, with the movements of occupation we are dealing with a different dynamic in which identity and its representation is no longer operative or important. Rather than making identities and interests - whether class, gender, ethnicity, sexuality etc. - visible to power through the articulation of demands, we see instead a convergence of people who no longer identify themselves in specific ways but who come together as singularities; who come together, as Giorgio Agamben would put it, 'purely anonymously' and 'without any representable condition of belonging' (Newman 2014: 94).
\end{abstract}

These movements form social relations which challenge the hierarchical structure of society built up by the antagonistic climate of politics. In this regard, political solidarity explores the possibility of a different kind of belonging which is not based on fixed identities and subjectivities.

It is striking to note that, as in the case of the solidarity of the shaken, these new subjectivities first appear in the form of bodily vulnerability. The solidarity of the shaken is originally a corporeal solidarity. On the front line, I experience by my body the epoche or reduction of my primordial relationship with the world ${ }^{3}$.

\footnotetext{
${ }^{3}$ For an investigation of epoché and front-line experience, see Meacham 2012 \& Cochereau 2016.
} 
Similarly, the collective corporeality of disobedience forms a body politics that neutralizes conventions and social norms. The liberation of the social ethos consists in bringing out the public space of collective bodily action. It is thus that civil disobedience becomes a political judgment that is first incorporated into the feeling of suffering and indignation, rather than linked to abstract reflection. In this regard, Judith Butler draws our attention to the following fact:

\begin{abstract}
An uprising does not come up from my indignation or from yours. Those who rise up do so together, recognizing that they suffer in ways that no one should. So an uprising requires a recognition not only that what the individual suffers is shared, but that a group is living beyond a shared sense of its limit. Individuals and groups both undergo subjugation and so in rising up, it is this body with other bodies, and from a shared refusal to live beyond the limit of what can be, or should be, endured (Butler 2016: 24).
\end{abstract}

It is also the case that the the bodies of the citizens constitute the place of disobedience against the prejudiced norms of society. They unite with the space of protest and transform its cultural and historical sense. An uprising upsets the boundaries between action and behavior, social and political. The vulnerability of spaces of protest can be thought only from the vulnerability of the body. Human vulnerability, such as that of human chains in protests, responds to violence by the symbolic force of solidarity. Citizens in protest risk their skin to affirm their dignity and their willingness to live freely. It is a political action, a disintegration of the ordinary order of things, a challenge against rules likely to normalize social behavior. The negatif character of it tries to show the distance between legality and legitimacy, between objective functionality and personnal responsability.

On the other hand, to the equal vulnerability of citizens to the violence of power are added differential vulnerabilities to the internal components of civil disobedience. A civil disobedience is a public action that can bring together citizens who do not necessarily share the same convictions. The participation of the political opponent in the same situation that makes us possible an agreement in difference or unity in discord (polemos) that opens a public space of equals in which one reaches freedom. 
In this light, one can speak of a relationship between the different vulnerabilities and the process of individuation of the resistants. Civil disobedience is not at all a juxtaposition of the different social identities. The juxtaposition of social identities (ideology, ethnicity, social class) is not enough to establish an authentic meaning of the polemos which is rooted in the tension of the differential positions of political actors. In this sense, the different groups gain their identities of dissent not from norms or roles pre-established but thanks to their singular political acts to each one.

As we already know, after the uprisings, using fear as a political tool, as an instrument of atomization of society, allowing its spiritual, political and moral enslavement, is a means of obedience and criminalization of collective action. The antagonistic atmosphere derives from economic, social and political arrangements which destroy plurality and solidarity and "event-ness" of the event without allowing for new meanings to emerge. What emerges from this is a condition of widespread social hypocrisy or "institutionalized lying", or "living in a lie". The violence of antagonism is thus to weaken the capacity of man to act on the public space. Antagonistic political space can be described as public space in which some groups in society have become the predominant actors and some are relegated to the place of sufferers. As Zeynep Gambetti writes "The violence of antagonism consists in impairing the capacity of human to act on the common world while being acted on by others" (Gambetti 2016: 1129). By contrast, polemic political space hinge on the egalitarian distribution of the capacity to act and be acted on by others. Individuation is the actualisation of the power-to-become of selves who, through their pluralistic encounters, constitute a collective site of power. Understood in this way, polemos would relate to the event-character of acces to the public space. In this regard, unlike the front-line or war zone, public space in in contemporary uprisings become the emblematic site in urban public consciousness for the production and regeneration of the political. 
In this context, since it is nonnegotiable through available norms, the space of coexistence of the various vulnerabilities of the internal components of resistance allows citizens to experience "publicness" in unforeseen ways. The actors of civil disobedience realize their own possibilities of action thanks to the other politically vulnerable "strangers". In this sense, such a public space has the potential to provide a stronger basis for political unity than communities based on "coalitions of interest". As Simon Critchley writes in his book Infinitely Demanding Ethics of Commitment Politics of Resistance:

\footnotetext{
The subject commits itself ethically in terms of a demand that is received from that situation, for example a situation of political injustice: a strike, an act of police brutality, a miscarriage of justice or whatever. But this demand is not reducible to the situation. It is, rather, a situated demand that is addressed, in principle, to everyone and hence universal (Critchley 2007: 42).
}

The ethical relationship is only possible through a demand for equality that goes beyond its particular situation. It is not only about equality in the economic sense, but about equality in the sense of a society in which there really is a production of the common. Collective action leaves everyone free to make their voices heard without establishing any hierarchy between them. The voice of disobedience is therefore indissolubly personal and collective, and the more it expresses the singular, the more it is capable of representing the collective. It is for this reason that, politial solidarity provides a model for how we might approach the delicate balance between individual commitment and collective action. 


\section{REFERENCES}

Butler, J. 2016. Uprising. Soulèvements (ed. G. Didi-Huberman, pp. 23-37). Paris: Gallimard.

Cochereau, M. (2016). Polemos ou le sens du conflit: guerre et politique chez Jan Patočka. Cahiers d'études lévinassiennes, 14: 46-69.

Crépon, M. (2007). La guerre continue: Note sur le sens du monde et la pensée de la mort. Studia Phænomenologica, VII: 395-409.

Critchley, S. (2007). Infinitely Demanding: Ethics of Commitment, Politics of Resistance. London and New York: Verso.

Douzinas, C. (2013). Philosophy and Resistance in the Crisis: Greece and the Future of Europe. Cambridge: Polity Press.

Eltchaninoff, M. (2016). Les Nouveaux dissidents. Paris: Stock.

Findlay, E. F. (2002). Caring for the Soul in a Postmodern Age: Politics and Phenomenology in the Thought of Jan Patočka. New York: SUNY Press.

Gambetti, Z. (2016). Risking Oneself and One's Identity: Agonism Revisited. Vulnerability in Resistance (ed. J. Butler, Z. Gambetti \& L. Sabsay). Durham and London: Duke University Press (Kindle edition).

Meacham, D. (2012). L'Europe, L'histoire et la vie: quelques réflexions sur la philosophie de l'histoire de Jan Patočka. Jan Patočka, Liberté, existence et monde commun (ed. N. Frogneux, pp. 239-251). Paris: Editions du Cercle Herméneutique.

Newman, S. (2014) Occupy and Autonomous Political Life. Radical Democracy and Collective Movements Today (ed. A. Kioupkiolis \& G. Katsambekis, pp. 93-111). Surrey, UK: Ashgate.

Patočka, J. (1988). Le monde naturel et le mouvement de l'existence humaine (trad. fr. E. Abrams). Dordrecht/Boston/London: Kluwer Academic Publishers.

Patočka, J. (1990). Liberté et sacrifice. Écrits politiques (trad. fr. E. Abrams). Grenoble: Million.

Patočka, J. (1996). Heretical Essays in the History of Philosophy (ed. James Dodd). Chicago\&La Salle, Illinois: Open Court.

Patočka, J. (1997). Platon et l'Europe. Séminaire privé du semestre d'été 1973 (trad. fr. E. Abrams). Lagrasse: Éditions Verdier. 166-169.

Patočka, Jan. 2009. Ce que la Charte 77 est et ce qu'elle n'est pas. Esprit 352: 

102.

Stranberg, G. (2015). The Solidarity of the Shaken. Baltic Worlds, 1-2, 101Scholz, J. S. (2012). Political Solidarity. Penn State University Press.

Tassin, É. (2009). Pensée hérétique et politique dissidente. Tumultes, 32-33 (1), 329-350. 